\title{
Csontkor - a csontrendszeri érettség mérésének lehetősége EOS készülékkel
}

\author{
O’Sullivan Ian dr. - Schlégl Ádám Tibor dr. - Varga Péter dr. \\ Kerekes Kamilla dr. - Vermes Csaba dr. - Than Péter dr.
}

Pécsi Tudományegyetem, Általános Orvostudományi Kar, Ortopédiai Klinika, Pécs

\begin{abstract}
Bevezetés: Az EOS 2D/3D rendszerrel készült felvételeken nem ábrázolódik megfelelően a csontkor megállapítására leggyakrabban használt kéz és csukló.

Célkitüzés: Kutatásunk célja, hogy alternatív csontkormérési lehetőségeket keressünk EOS-felvételeken való alkalmazásra.

Módszer: 9 mérési módszer bevonásával pilotvizsgálatot végeztünk, amely alapján 5 módszert válogattunk be: nyaki csigolyát (Hassel-Farman), csípólapátot (Risser 'plus'), térdet (O'Connor), sarokcsontot (Nicholson), csípőt (Oxford) értékelve. 114 egészséges, 2-21 éves eset EOS-felvételein intra- és interobszerver megbízhatósági vizsgálatot végeztünk, valamint Spearman-korrelációval összevetettük a csont- és kronológiai kort.

Eredmények: A megbízhatósági vizsgálatok minden módszer esetében kiváló eredményt adtak (csoporton belüli korreláció $>0,9)$, kivéve az O’Connor-módszert $(0,865$ - jó). A Nicholson- és a Hassel-Farman-módszer bizonyult a leggyorsabbnak (átlag: 17,5 mp és 33,4 mp), viszont a sarokcsontok 14\%-a nem volt vizsgálható (a cervicalis esetén $1 \%)$. Minden módszer szignifikáns összefüggést mutatott a korral (korrelációs koefficiens $>0,829$ ). Az értékelésnél nehézséget jelentettek a nem ábrázolódó (12\%) vagy egymásra vetülő $(23 \%)$ csontrészek.

Következtetés: Csontkor-megállapítás mind az 5 módszer alkalmazásával lehetséges, de kiemelkedett a nagy megbízhatósággal, gyorsan, közel az összes felvételen alkalmazható Hassel-Farman-módszer.

Orv Hetil. 2019; 160(16): 619-628.
\end{abstract}

Kulcsszavak: EOS 2D/3D, csontkor, biológiai kor, kronológiai kor, Risser-jel

\section{Bone age - alternatives for skeletal maturity assessment for the EOS scanner}

Introduction: Hand and wrist bone age assessment methods cannot be performed when using the recommended patient position within the EOS scanner.

Aim: We aimed to assess alternative methods for use with the EOS.

Method: After investigating 9 alternatives, five methods were selected - cervical vertebra (Hassel-Farman), iliac crest (Risser 'plus'), hip (Oxford), knee (O'Connor), calcaneus (Nicholson) - and applied to EOS scans of 114, 2-21-yearold normal individuals. Intraclass correlation coefficient tests for reliability and Spearman correlation with calendar age were assessed.

Results: Intra- and interobserver reliabilities were all excellent, except with the knee method (0.865 - 'good'). Calcaneal and cervical methods were the fastest to apply (mean $17.5 \mathrm{~s}, 33.4 \mathrm{~s}$ per evaluation), however, calcanei were unassessable in $14 \%$ of scans (versus $1 \%$ of cervical). All methods correlated significantly with calendar age $(r>0.829$, $\mathrm{p}<0.05)$. Difficulties were principally absent $(12 \%)$ or obscured $(23 \%)$ landmarks.

Conclusion: Bone age assessment is possible with all 5 methods, however, the Hassel-Farman method proved to be easily useable, fast and reliable.

Keywords: EOS 2D/3D, bone age, biological age, calendar age, Risser sign

O’Sullivan I, Schlégl ÁT, Varga P, Kerekes K, Vermes Cs, Than P. [Bone age - alternatives for skeletal maturity assessment for the EOS scanner]. Orv Hetil. 2019; 160(16): 619-628.

(Beérkezett: 2018. október 19.; elfogadva: 2018. november 24.) 


\section{Rövidítések}

$2 \mathrm{D}=$ kétdimenziós; $3 \mathrm{D}=$ háromdimenziós; $\mathrm{CT}=($ computed tomography) számítógépes tomográfia; EOS = sztereo-röntgenfelvételi rendszer, mely álló vagy ülő helyzetben készít képet a teljes testről; ICC $=$ (intraclass correlation $)$ osztályon belüli korreláció; $\mathrm{kk}=$ korrelációs koefficiens, korrelációs együttható; MRI = (magnetic resonance imaging) mágnesesrezonancia-vizsgálat

A csontkor a vázrendszer érettségi állapotának jó indikátora. Egy vagy több csont másodlagos csontosodási magjának elemzésével lehetôségünk nyílhat megbecsülni a teljes csontváz biológiai korát. A növekedés állapotának és ütemének megállapítása fontos támpontot nyújthat endokrinológiai, fogorvostani és ortopédiai betegségek diagnosztizálásához és beavatkozások időzítéséhez [1].
Emellett fontos információkat nyújthat az igazságügyi orvoslás és az antropológia vonatkozásában.

A XIX. század vége óta számos csontkormérési módszert publikáltak - egyes módszerek már a méhen belüli fejlődést is értékelik, míg más mérôszámok nem mutatnak jelentős változásokat a késői serdülőkorig; egyesek az epiphysisporcokat elemzik, míg mások az apophysisek csontosodásának változásait; sokan csak hosszú csöves csontokat értékelnek, mások csak lapos vagy szabálytalan csontokat, míg egyesek egy érintett régió különböző típusú csontjait veszik figyelembe (1. táblázat) [2-30]. A különböző régiók vizsgálatához számos képalkotó módszert használtak, a hagyományos röntgenképalkotástól (ez a legáltalánosabban használt) az ultrahangon és a CT-n át az MRI-ig [31].

A témakör régóta kiterjedt vizsgálata ellenére továbbra is maradtak válaszra váró kérdések, amelyek a növekedés

1. táblázat | Népszerú csontkormérési módszerek - az atlasz- és az 'egyrégió'-módszer [2-30]

\begin{tabular}{|c|c|c|c|c|}
\hline & Atlaszmódszer & & Egyrégió-módszer & \\
\hline \multirow[t]{7}{*}{ Kéz és csukló } & Greulich-Pyle & Greulich \& Pyle, 1959 [2] & Björk & Björk, 1967 [3] \\
\hline & & & Fishman $^{\dagger}$ & Fishman, 1982 [4] \\
\hline & & & Grave \& Brown & Grave \& Brown, 1976 [5] \\
\hline & & & Oxford Hand-Wrist & Acheson, 1954 [6] \\
\hline & & & Sanders & Sanders, et al. 2008 [7] \\
\hline & & & Singer ${ }^{\dagger}$ & Singer, $1980[8]$ \\
\hline & & & Tanner-Whitehouse & Tanner et al., 1976 [9] \\
\hline \multirow[t]{4}{*}{ Nyaki csigolya } & & & Hassel \& Farman & Hassel \& Farman, 1995 [10] \\
\hline & & & Lamparski & Lamparski, 1975 [11] \\
\hline & & & Mito & Mito et al., 2002 [12] \\
\hline & & & Roman & Roman, et al. 2002 [13] \\
\hline Felkarcsont & & & Walker \& Lovejoy & Walker \& Lovejoy, 1985 [14] \\
\hline \multirow[t]{2}{*}{ Könyök } & & & Sauvegrain & Sauvegrain, $1962[15]$ \\
\hline & & & $\begin{array}{l}\text { Sauevegrain (módosított): } \\
\text { csak Olecranon }\end{array}$ & Charles et al., 2007 [16] \\
\hline Váll & & & Schaefer & Schaefer et al., 2015 [17] \\
\hline Kulcscsont & & & Schmeling & Schmeling et al., $2000[18]$ \\
\hline Első borda & & & Michelson & Michelson et al., 1934 [19] \\
\hline \multirow[t]{2}{*}{ Csípő, csípőlapát } & & & Risser & Risser, 1958 [20] \\
\hline & & & Risser 'plus' & Negrini et al., 2015 [21] \\
\hline Symphysis & & & McKern \& Stewart & McKern \& Stewart, 1957 [22] \\
\hline \multirow[t]{2}{*}{ Csípő } & & & Oxford-csípő & Acheson, 1957 [23] \\
\hline & & & Módosított Oxford-csípő & Stasikelis et al., 1996 [24] \\
\hline Femurdiaphysis & & & Stull & Stull et al., 2014 [25] \\
\hline Szárkapocscsont & & & Tsai & Tsai et al., $2016[26]$ \\
\hline \multirow[t]{2}{*}{ Térd } & Pyle \& Hoerr & Pyle \& Hoerr, 1969 [27] & McKern-Stewart & O'Connor et al., 2008 [28] \\
\hline & & & Oxford-térd & Acheson, 1954 [6] \\
\hline Boka & Hoerr, Pyle \& Francis & Hoerr et al., 1962 [29] & & \\
\hline Sarokcsont & & & Nicholson & Nicholson et al., 2015 [30] \\
\hline
\end{tabular}

†Jellemzően ortodontologiában és fogorvoslásban használt módszerek. 
- amely dinamikus, változó jelenség - nehéz számszerüsíthetőségéből és magas egyéni különbségeiből is adódnak: egy adott régióban tapasztalható csontkorból egyenesen következik-e a vizsgált egyén biológiai kora? Egy adott egyén növekedési üteme megbízhatóan összehasonlítható-e másokéval? Számos szerző figyelmeztet a túlzott egyszerüsítés veszélyeire, illetve az egyetlen mutató alapján történő növekedésbecslés megbízhatatlanságára. Biztosabb becslést lehet végezni a magassággörbék, a Tanner-stádiumok (a pubertás fejlődési szakaszai) és egy vagy több csontkormérési módszer kombinálásával [32].

A röntgenalapú csontkorbecslési módszerek két csoportba oszthatók, ezek az atlaszmódszer és az egyrégiómódszer.

- Az atlaszalapú módszerek olyan referenciaképeket használnak, amelyekhez a páciens röntgenfelvétele hasonlítható. A vizsgált csont(ok)nak a referenciaképekhez való illesztése után meghatározható a csontváz érettségi szintjének megfelelő kronológiai kor, azaz a csontkor. A fenti módszerek népszerúségét az adja, hogy könnyű őket megtanulni és használni, azonban könnyen téves eredményt adhatnak a növekedést egységes folyamatként kezelő megközelítések. Ezen okból az atlaszmódszerek pontossága elmarad az egyrégiós módszerekétól. Példaként említhető a GreulichPyle-féle kéz- és csuklóatlasz [2].

- Az egyrégiós megközelítés egy kiszemelt régió fejlődését elemzi, és fejlődési szakaszok formájában vagy százalékos formában kapunk eredményt. Az értékek csak az adott régió fejlődését írják le; a test többi részének fejlődésétől függetlenül eltérő időpontban érik el a legfejlettebb stádiumot, vagyis a 100\%-ot. Ezek a módszerek általában pontosabbak, de gyakran hoszszabb időt vesz igénybe a begyakorlásuk, és a kapott eredmények nem kapcsolódnak közvetlenül a kronológiai korhoz, ami az értelmezésüket megnehezíti. A kronológiai korhoz való lazább kapcsolat következtében kevésbé jellemző a túlegyszerúsítés és a teljes testre való túlzott általánosítás. Ezt a megközelítést használja a Tanner-Whitehouse-, az Oxford-csípő-, a calcaneus- és a Hassel-Farman-módszer is $[6,10,30$, 33].

A leggyakrabban használt technikák a kéz és a csukló felmérésén alapulnak, úgymint a Greulich-Pyle- vagy a Tanner-Whitehouse-módszer. Ezek során a bal oldali alkarról és csuklóról történik hagyományos anteroposterior röntgenfelvétel. A bal oldalt antropológusok egyezményesen választották ki az 1900-as években, mivel általában ez a nem domináns kéz, ezért a sérülése kevésbé valószínü [2].

Klinikánknak több mint 13 éves tapasztalata van az EOS 2D/3D rendszerrel [34-37], mely kétirányú teljestest-röntgenfelvételt lehetővé tévő képalkotó, amely utólagos 3D-rekonstrukcióra is alkalmas. A technika többek között hozzájárult az alsó végtagok biomechanikájának megértéséhez a növekedésben lévő gyermekek- nél. A képalkotás során a páciensek a bal lábukkal 5 cmrel elörelépve állnak, a karok pedig elöl, könyökben és csuklóban hajlítva vannak. Ez a testtartás nem teszi lehetővé a csontkor-meghatározás tipikus alkar- és csuklóalapú módszereinek használatát, így szükségessé vált EOSkompatibilis alternatív módszerek keresése.

Klinikánk korábbi vizsgálataiban igazoltuk a fogorvosok által széles körben használt nyakicsigolya-morfológián alapuló Hassel-Farman-módszer EOS-képalkotással kompatibilis magas megbízhatóságát [35].

Korábbi vizsgálatunkra alapozva a jelen tanulmány célja, hogy felmérjük az EOS 2D/3D felvételeken alkalmazható csontkormérési módszereket, elemezzük alkalmazhatóságukat, majd elvégezzük megbízhatósági vizsgálatukat.

\section{Módszer}

Klinikánkon 2007 és 2017 között a rutin ambuláns ellátás során 7127 EOS-teljestest-felvétel készült. Ebből kiválogattuk azokat az eseteket, amelyek a 2-21 éves korosztályt ábrázolták, és nem szerepelt az anamnézisükben olyan betegség vagy mútét, mely a csontváz növekedését befolyásolhatta, illetve a beteg a vizsgálat során nem mozdult meg (ami elmosódottá tette a képet), és megfelelően pozicionálták. Az így megmaradt 1005 esetből véletlenszerüen, az életkor egyenletes eloszlását szem elött tartva kiválasztottunk 114-et ( 57 férfi, 57 nő).

Az irodalom áttekintését követően kiválogattuk azokat a csontkormérési módszereket, melyek a legnagyobb eséllyel alkalmazhatók EOS-felvételeken: nyaki csigolya [10], váll [17], kulcscsont [18], első borda [19, 38], könyök [15], csípólapát - Risser 'plus' [20], csípő (medence és proximalis combcsont) [23], combcsontdiaphysis [25], térd [28] és sarokcsont [30] (1/a-e. ábra).

Egy pilotvizsgálat során 13 véletlenszerüen választott eseten, 3 vizsgáló bevonásával teszteltük a módszereket. A kulcscsonton, első bordán, könyökön és combcsontdiaphysisen alapuló méréseket kivitelezhetetlennek találtuk, majd a vizsgálatot követően, a vizsgálók szubjektív benyomása alapján a vállalapú módszert is kizártuk (részletek az Eredmények címú fejezetben).

A pilotvizsgálat eredményei alapján mind a 114 esetben elvégeztük a mérést a nyakicsigolya-, a csípólapát-, a csípő-, a térd- és a sarkcsontalapú módszereket alkalmazva. Ahhoz, hogy meghatározzuk, melyik módszer lenne a legmegfelelőbb, leghasznosabb a klinikai gyakorlatban EOS-képek értékelésénél, felmértük az alábbiakat:

\section{1) A módszerek megbizhatósága}

Különböző vizsgálók milyen eséllyel értékelik ugyanúgy a csontkorérési stádiumot (interobszerver), valamint a módszer milyen könnyen tanulható és reprodukálható a vizsgálók által (intraobszerver).

30 eset bevonásával is elvégeztük a vizsgálatot, melynek során 3 vizsgáló 3 különböző napon 3 alkalommal elvégezte a felvételek értékelését mind az 5 megmaradt 

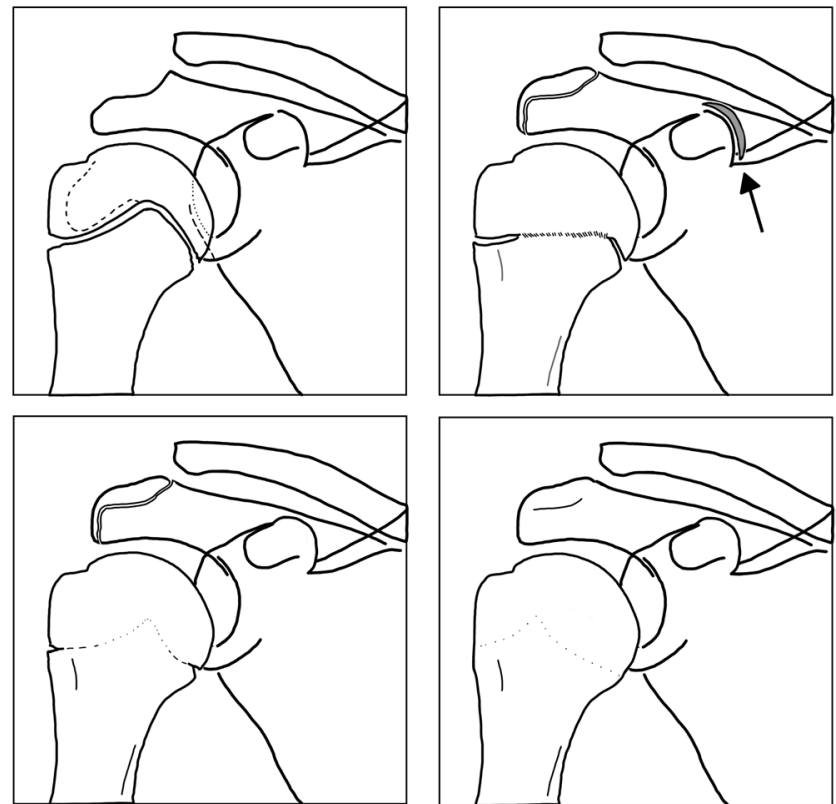

1/a-e ábra

A pilotvizsgálatba bevont csontkormérési módszerek (A nyakicsigolya-módszer leírása a Schlégl et al. 2017-ben megjelent cikkben található)

1/a ábra

$$
\begin{aligned}
& \text { Váll (Shaefer et al., 2015). A váll } 3 \text { régióját értékeli anteroposte- } \\
& \text { rior röntgenfelvételeken. } 4 \text { stádiumot különít el, igaz, nem } \\
& \text { mindegyik ábrázolódik röntgenfelvételeken. A régiók értékelé- } \\
& \text { sének összege adja a végsó beosztást. } \\
& \text { Proximalis humerus } \\
& \text { 1. stádium - nyitott: az epiphysis mentén folyamatos radiolu- } \\
& \text { cens vonal figyelhetố meg. Az epiphysis éretlennek túnik, a szé- } \\
& \text { li részek még nem fejlődtek ki teljesen. } \\
& \text { 2. stádium - egyesülés: elkezdődött az összecsontosodás. Az } \\
& \text { epiphysisporc centrális területén homály/elmosódottság jelenik } \\
& \text { meg. A csontosodás előrehaladtával a teljes vonal elmosódottá } \\
& \text { válhat, de még egyértelmúen azonosítható. } \\
& \text { 3. stádium - széli bevágás: közel teljes összecsontosodás, csak a } \\
& \text { széles részeken marad vissza radiolucens 'bevágás'. Jellemzóen a } \\
& \text { tuderculum majus alatt figyelhető meg. } \\
& 4 \text { stádium - teljes egyesülés: teljes összecsontosodás, nincs radi- } \\
& \text { olucens terület. A fúziós vonal esetenként még felismerhető. } \\
& \text { Acromion } \\
& \text { 0. stádium - hiányzik: nem figyelhető meg apophysis. Az acro- } \\
& \text { mion felülete lekerekített, esetleg hullámos. } \\
& \text { l. stádium - megjelent: megfigyelhető apophysis, de még hatá- } \\
& \text { rozott radiolucens vonal választja el. } \\
& \text { 4. stádium - teljes egyesülés: teljes összecsontosodás, nincs } \\
& \text { radiolucens terület. } \\
& \text { Apex } \\
& \text { l. stádium - megjelent: megfigyelhető, az apophysis jól látható, } \\
& \text { de egyértelmú radiolucens vonal választja el }
\end{aligned}
$$

módszer alkalmazásával. A megbízhatóságot osztályon belüli korrelációs vizsgálattal elemeztük, az eredményeket a Winer-kritériumok alapján értékeltük $(0-0,24$ : nincs vagy gyenge; $0,25-0,49$ : alacsony; $0,50-0,69$ : közepes; 0,70-0,89: jó; és 0,90-1,00: kiváló) [39]. Egyúttal rögzítettük a vizsgálók tapasztalatait és a mérés kivitelezhetőségét.

\section{2) A vizsgálatok értékelhetôsége}

Az adott módszer milyen arányban és mennyire nehezen alkalmazható EOS-felvételeken, továbbá az esetleges problémáknak mi az oka.
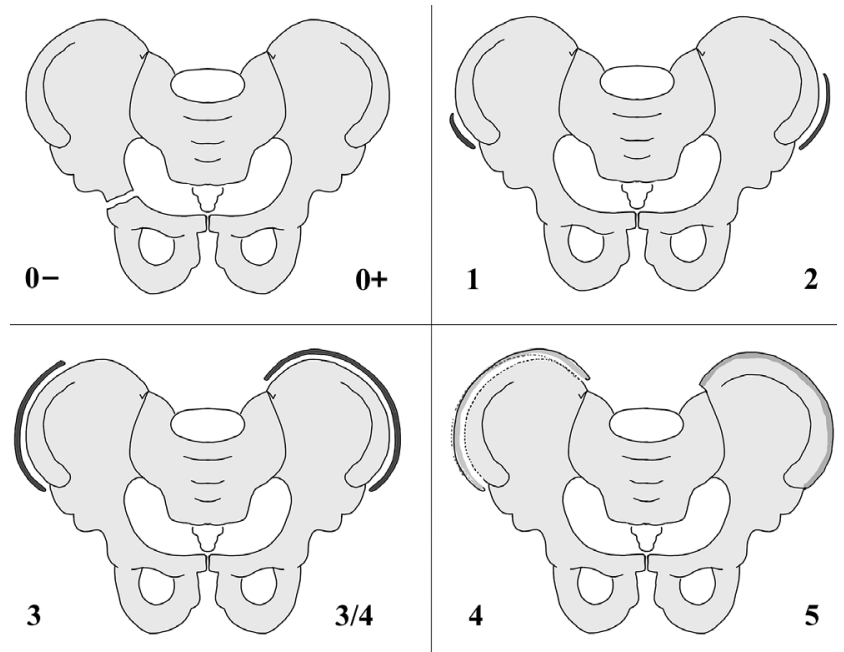

1/b ábra

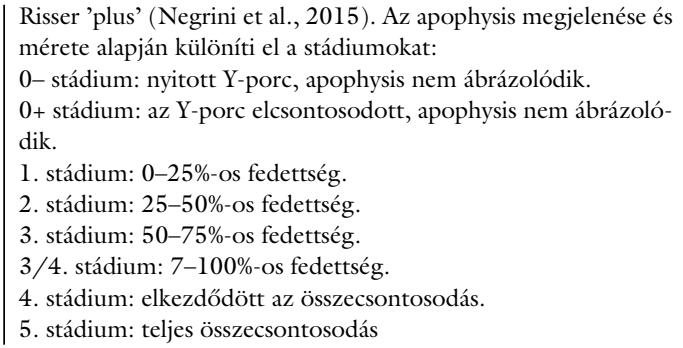

Ehhez a vizsgálók értékelték a módszer szubjektív alkalmazhatóságát egy 4 pontos skálán: 'l' - könnyü: könnyen alkalmazható; '2' - közepes: néhány kisebb nehézség, azonban a mérés határozottan kivihetó; '3' - nehéz: közepes nehézségek, az értékelendő terület egy része (1/3-a vagy kevesebb) nem ábrázolódott megfelelően, a mérés nem volt teljes biztonsággal kivitelezhető; '4' - lehetetlen: az értékelendő terület nem ábrázolódott megfelelően. Azoknál a módszereknél, amelyekkel több régiót kellett értékelni, a vizsgálók külön-külön állapították meg az alkalmazhatóságot, melyet összesítettünk. Abban az esetben, ha legalább 2 régióra közepes értékelés érkezett, nehéznek minősítettük az alkalmazhatóságot, és ha legalább 2 nehéz értékelést kapott, akkor lehetetlennek.

Lejegyeztük az alkalmazhatóság nehézségeinek okát, amelyeket 3 csoportra osztottunk: technikai okok (a vizsgálandó régió nem jelent meg a felvételen), felbontási problémák (például nehézséget jelentett annak megállapítása, hogy az epiphysisporc teljesen záródott-e, vagy vannak még radiolucens régiók), pozicionálási problémák (a vizsgált régió nem a megfelelő irányból ábrázolódott, vagy más csontrész belevetült).

\section{3) A kivitelezés gyorsasága}

A vizsgálat elvégzéséhez szükséges idő egyértelmúen befolyásolja annak klinikai és kutatási célra történő alkalmazhatóságát. 


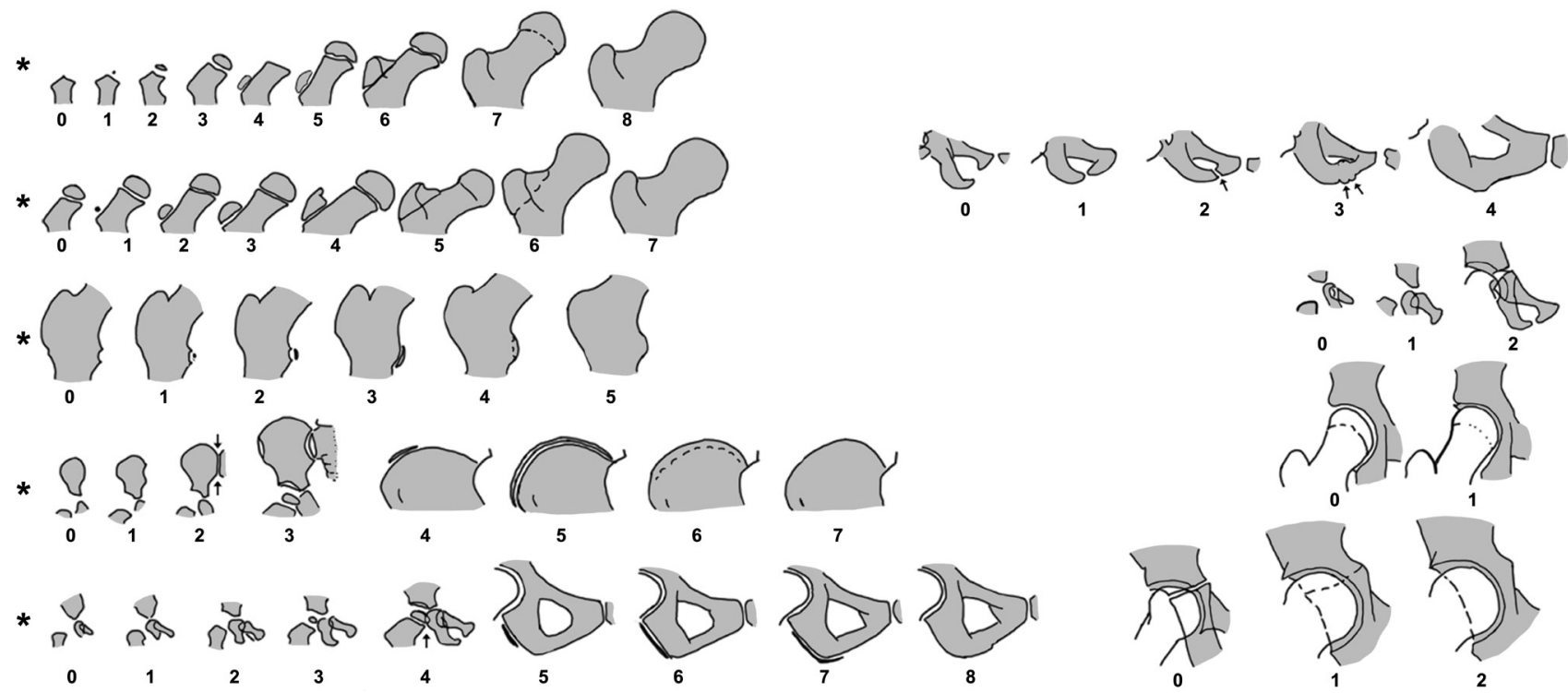

1/c ábra $\quad$ Oxford-csípő (Acheson, 1957). 9 régió értékelésével és a kapott eredmények összegzésével ad 0-45 közötti értéket. A módosított Oxford-csípő-módszer (Stasikelis et al. után) csak 5 régiót értékel ( ${ }^{*}$-gal jelölve) (Az ábrát az Acheson 1957 -es cikkben megjelent képek alapján készítettük)
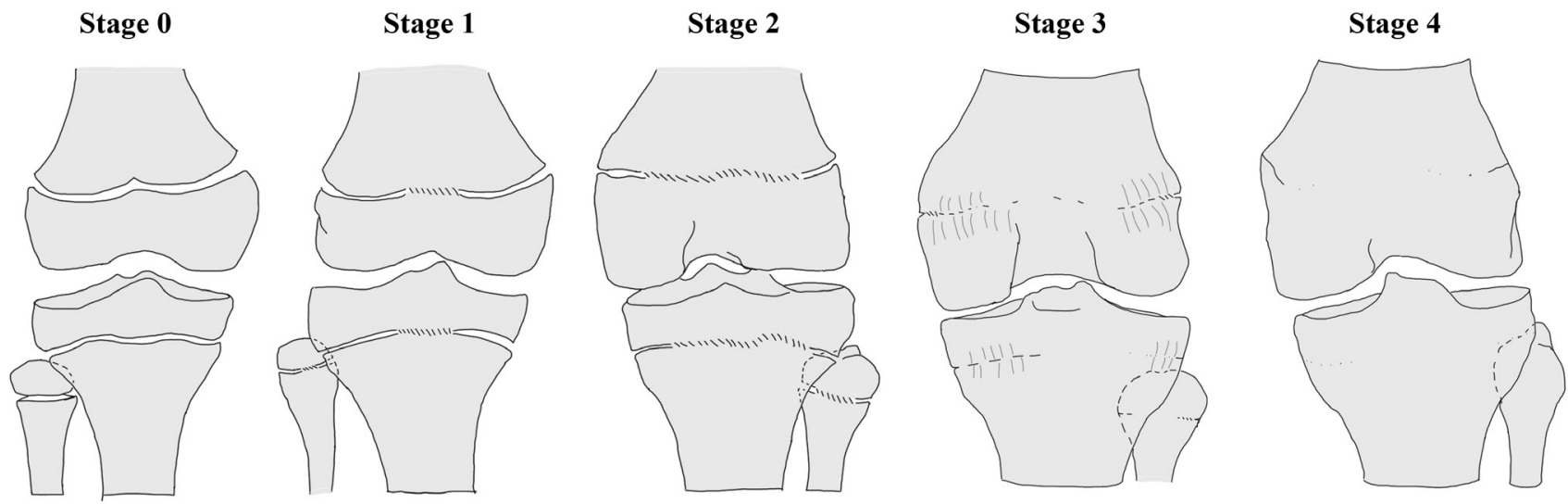

$1 / \mathrm{d}$ ábra

Térd (O’Connor et al., 2008). Anteroposterior és oldalirányú röntgenfelvételek alapján értékeli a femur distalis, illetve a tibia és a fibula proximalis epiphysisét, majd összegzi a kapott pontszámokat.

0. stádium - nyitott: tiszta radiolucens sáv az epi- és a metaphysis között.

1. stádium - kezdődő egyesülés: nagyon vékony radiolucens sáv, a centrális rész elmosódott/elhomályosodott a kezdődő összecsontosodás miatt (a felületi kevesebb mint 50\%-án).

2. stádium - aktív egyesülés: 'sapkaképződés' (capping), az epiphysis túlnyúlik a metaphysisen. A csontosodási zóna meghaladja az 50\%-ot, de még vannak teljesen radiolucens területek.

3. stádium - nemrég lezajlott egyesülés: finom fúziós vonal még megfigyelhető, de az epi- és a metaphysis egyesült. A széleken még előfordulhat 2 mm-nél kisebb 'bevágás'. A trabeculavonalak nem folytonosak az epi- és a metaphysis között.

4. stádium - teljes egyesülés: érett csont, nincsenek bevágások a széleken, folyamatosak a trabeculák. Vékony „epiphysisheg” megmaradhat az epiphysisporc vonalának megfelelően

A statisztikai analízis során Spearman-korrelációt alkalmaztunk a naptári és a csontkor összefüggésének vizsgálatára, valamint független mintás t-próbát a csoportok közti különbség megállapítására (IBM SPSS v23, IBM Corp., Armonk, NY, USA). A randomizáláshoz a Microsoft Excel vl4.0.6112.5000 (Microsoft Corp., Redmond, WA, USA) VÉLETLEN.KÖZÖTT függvényét alkalmaztuk. A p<0,05-öt tekintettük szignifikánsnak.

\section{Eredmények}

A váll értékelésén alapuló módszert a pilotvizsgálat során nem találtuk az EOS-technikával kompatibilisnek, és kizártuk a vizsgálat további részéből, mivel a megfigyelők a vizsgálatok $54-72 \%$-ában a régió értékelését ellehetetlenító nehézségeket tapasztaltak. Az esetek 23-38\%ában három vizsgált régió közül csak egy ábrázolódott 

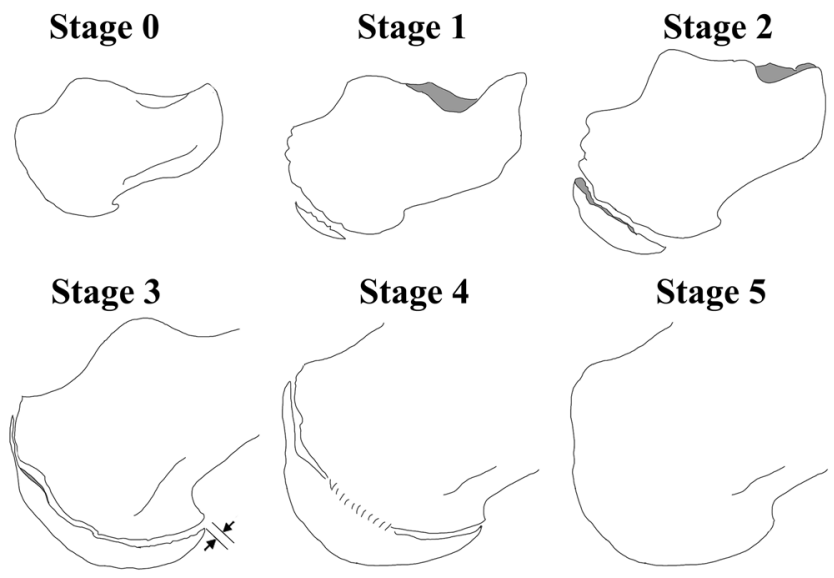

1/e ábra

Sarokcsont (Nicholson et al., 2015). A sarokcsont oldalirányú felvétele alapján értékel.

O. stádium: nincs csontosodás az apophysis területén.

l. stádium: megjelenik csontosodás az apophysis területén, de nem haladja meg a metaphysis felületének $50 \%$-át.

2. stádium: az apophysis területének több mint $50 \%$-át borítja csontosodott terület, de nem ér talpi felszínt. A radiolucens terület az apophysis és a metaphysis között szélesebb a talpi és a dorsalis részen, mint a centrális területen.

2+ stádium: a távolság az apophysis talpi csúcsa és a metaphysis processus medialis/lateralis tuberis calcaneinek megfelelő szöglettörése között 2-5 mm

3. stádium: az apophysis teljesen fedi a metaphysist (a $2+$ stádiumban leírt távolság $2 \mathrm{~mm}$-nél kisebb - fekete nyíl az ábrán), de határozott radiolucens terület választja el tőle. Az apophysis és a metaphysis közötti távolság egységes a teljes felszínen.

4. stádium: megjelentek az apophysis és a metaphysis összecsontosodásának jelei, de még egyértelmúen elkülöníthető a két struktúra. A csontosodás a centrális régióban kezdődik, és fokozatosan halad a széli részek felé.

5. stádium: teljes összecsontosodás

megfelelő́n (13-ból 3-5 vizsgálatban), a processus coracoideus csúcsa/szöge nem volt látható 15-38\%-ban (13ból 2-5 esetben), továbbá a megfigyelók alacsony elégedettségről számoltak be a módszerrel kapcsolatban.

Így 5 módszer esetében végeztük el a klinikai alkalmazhatóság értékelését.

\section{Megbizhatóság}

$\mathrm{Az}$ intraobszerver megbízhatósági pontszámok mindegyike kiváló volt a térd vizsgálatán alapuló módszer kivételével, ahol a 2 -es vizsgáló csak jó eredményt ért el (1. vizsgáló: 0,$945 ; 2$. vizsgáló: $0,841,3$. vizsgáló:
0,956). Az interobszerver megbízhatósági vizsgálat során minden módszer „kiváló” értékelést kapott, kivéve a térd- és a módosított Oxford-csípő-módszert, amelyek a „jó” kategóriába estek. Az értékek csökkenő sorrendben: nyakicsigolya- $(0,976)$, sarokcsont- $(0,945)$, Risser 'plus'- $(0,940)$, Oxford-csípő- $(0,902)$, módosított Oxford-csípő- $(0,887)$ és térd- $(0,865)$ módszer (lásd bővebben a 2. táblázatban). A Winer-kritériumok alapján 0,7 felett a megbízhatóság jónak mondható, ugyanakkor a vizsgálók a térdmódszer esetében alacsony elégedettségrốl számoltak be, ezért úgy éreztük, a kapott megbízhatósági érték magasabb az elvártnál. Ez a magas érték adódhat ugyanakkor abból is, hogy a vizsgált populáció jelentős része a könnyen értékelhető 0 . stádiumba került, mivel a térd körüli epiphysisek értékelhető változásai csak serdülőkorban kezdődnek.

\section{A vizsgálatok értékelhetösége}

A vizsgálatba bevont 114 személy esetén a legtöbb csontkorbecslési módszert a megfigyelők „egyszerúen elvégezhetőnek" minősítették a Risser 'plus'-(111/114, $97 \%$ ), a térd- (110/114,96\%), a nyakicsigolya- (a vizsgálatok 98,02\%-ában - a korábbi vizsgálataink alapján, részletek: [35]) és az Oxford-csípó- (102/114, 89\%) módszer esetén. A sarokcsonti módszerrel 114 vizsgálatból 72 „könnyü”, 13 „közepes” minősítést kapott, ugyanakkor 29 vizsgálatot (25\%) volt „nehéz” vagy „lehetetlen" értékelni. A megfigyelők értékeléseinek eredményeit a 3. táblázatban részleteztük, illetve a 4. táblázatban a vizsgálati nehézségek okait tüntettük fel.

\section{Idöfaktor}

Az utolsó 30 képelemzés során mért vizsgálati idő alapján a leggyorsabban értékelhető módszernek a sarokcsont megítélése bizonyult (átlagosan 17,5 mp), míg a Risser 'plus'- (26,3 mp), a nyakicsigolya- $(35,4 \mathrm{mp})$, a térd- $(58,9 \mathrm{mp}$ ) és az Oxford-csípó- (149,0 mp) módszert lassabban elvégezhetőnek találtuk. A módosított Oxford-csípő-módszert az Oxford-csípő-értékekből számítottuk ki, így külön mérési idővel kapcsolatos adatokat nem gyújtöttünk.

A csontkorértékelések legfontosabb eredményeit az egyének kronológiai korával összehasonlítva a 2. ábrán $(\mathrm{a}-\mathrm{c})$ mutatjuk be. A kronológiai kor és a csontkor kö-

2. táblázat |Az inter- és intraobszerver megbízhatósági vizsgálat eredményei

\begin{tabular}{|c|c|c|c|c|c|c|}
\hline & Sarokcsont & Nyaki csigolya & Térd & $\begin{array}{l}\text { Módosított } \\
\text { Oxford-csípő }\end{array}$ & Oxford-csípő & Risser 'plus' \\
\hline Interobszerver megbízhatóság & 0,945 & 0,976 & 0,865 & 0,887 & 0,902 & 0,940 \\
\hline Intraobszerver megbízhatóság & $0,953-0,999$ & $0,949-0,959$ & $0,841-0,956$ & $0,975-0,993$ & $0,949-0,993$ & $0,982-0,969$ \\
\hline
\end{tabular}

A megbízhatóságot osztályon belüli korreláció alapján vizsgáltuk. Az osztályon belüli korrelációs koefficienseket (ICC) a Winer-kritériumok alapján értékeltük: ICC $\geq 0,90$ - kiváló; ICC: 0,70-0,89 - jó; ICC: 0,50-0,69 - közepes; ICC $\leq 0,49$.

Az intraobszerver megbízhatóságnál a három vizsgáló által elért legmagasabb és legalacsonyabb értéket adtuk meg. 
3. táblázat |A vizsgálók szubjektív értékelése

\begin{tabular}{lcccc}
\hline & $\begin{array}{c}1- \\
\text { könnyü }\end{array}$ & $\begin{array}{c}2- \\
\text { közepes }\end{array}$ & $\begin{array}{c}3- \\
\text { nehéz }\end{array}$ & $\begin{array}{c}4- \\
\text { lehetetlen }\end{array}$ \\
\hline Sarokcsont & 72 & 13 & 15 & 14 \\
\hline Nyaki csigolya $^{1}$ & - & - & - & - \\
\hline Térd & 110 & 4 & 0 & 0 \\
\hline $\begin{array}{l}\text { Módosított } \\
\text { Oxford-csípö }\end{array}$ & - & - & - & - \\
\hline Oxford-csípö* $^{*}$ & 102 & 3 & 9 & 0 \\
\hline Risser 'plus' & 111 & 3 & 0 & 0 \\
\hline
\end{tabular}

A vizsgálók értékelésének összesítése: 'l' - könnyű: könnyen alkalmaz ható; '2' - közepes: néhány kisebb nehézség, azonban a mérés határozottan kivihető; '3' - nehéz: közepes nehézségek, az értékelendő terület egy része ( $1 / 3$-a vagy kevesebb) nem ábrázolódott megfelelően, a mérés nem volt teljes biztonsággal kivitelezhető; '4' - lehetetlen: az értékelendő terület nem ábrázolódott megfelelően. Azoknál a módszereknél, amelyekkel több régiót kellett értékelni, a vizsgálók külön-külön állapították meg az alkalmazhatóságot, melyet összesítettünk. Abban az esetben, ha legalább 2 régióra közepes értékelés érkezett, nehéznek minősítettük az alkalmazhatóságot, és ha legalább 2 nehéz értékelést kapott, akkor lehetetlennek.

* 17 esetben az Oxford-csípő-módszer könnyü értékelést kapott, bár a vizsgálók nehézségekról számoltak be a kistrochanter értékelésekor. ${ }^{1}$ A nyaki csigolyára vonatkozó eredményeket korábbi vizsgálatunk tartalmazza [9].

${ }^{2}$ A módosított Oxford-csípő a hagyományos módszerből számítható így erre vonatkozóan nem végeztünk külön értékelést.

zötti összefüggést a Spearman-korrelációval vizsgálva a következő eredményeket kaptuk: nyaki csigolya (korrelációs koefficiens $[\mathrm{kk}]=0,829)$, sarokcsont $(\mathrm{kk}=0,903)$, Risser 'plus' ( $\mathrm{kk}=0,882)$, Oxford-csípő ( $\mathrm{kk}=0,934)$, módosított Oxford-csípő $(\mathrm{kk}=0,932)$ és térd $(\mathrm{kk}=$ $0,912)$.

A csontkor alapján felállított stádiumokat a férfi páciensek a nőkhöz képest magasabb kronológiai korban érték el (átlagosan 1,2-1,9 évvel később értek el a fiúk egy adott csontkorérettségi stádiumot, mint a lányok), azonban a különbségek többsége nem volt statisztikailag szignifikáns.

\section{Megbeszélés}

A csontérettség kronológiai kortól független első vizsgálata Londonban a Guy's Hospitalban dolgozó John Poland nevéhez füződik az 1898-ban megjelent 'Szkiagrafikus atlasz a kéz- és csuklócsontok fejlettségéről' kapcsán. A téma az 1930-as években kifejezetten népszerûvé vált az Egyesült Királyságban és az Amerikai Egyesült Államokban [40-42]. Miután a kronológiai kor csak az idő múlását mutatja, a kutatók régóta keresik annak lehetőségét, hogy a gyermek fejlődésének tényleges szintjét különböző vizsgálatokkal megállapítsák. Az utóbbit számtalan tényező befolyásolja, például a növekedési- és pajzsmirigyhormon-szintek, a genetikai sajátosságok, a szocioökonómiai státusz, a táplálkozás, a felszívódási zavarok, a cukorbetegség. A kronológiai kor és
4. táblázat Nehézségek a felvételek értékelésekor.

Abszolút értékek, valamint a problémák százalékos megoszlása

(a) A nehéz vagy lehetetlen értékelések okainak megoszlása

\begin{tabular}{|c|c|c|c|c|}
\hline & \multirow{2}{*}{$\begin{array}{l}\text { A 'nehéz' } \\
\text { vagy } \\
\text { 'lehetetlen' } \\
\text { értékelések } \\
\text { száma }\end{array}$} & \multicolumn{3}{|c|}{ Ok } \\
\hline & & Felbontás & $\begin{array}{l}\text { Pozicioná- } \\
\text { lás }\end{array}$ & $\begin{array}{l}\text { Technikai } \\
\text { probléma }\end{array}$ \\
\hline Sarokcsont & 29 & - & $1(3 \%)$ & $28(97 \%)$ \\
\hline Nyaki csigolya $^{1}$ & - & - & - & - \\
\hline Térd & 0 & - & - & - \\
\hline $\begin{array}{l}\text { Módosított } \\
\text { Oxford-csípő }\end{array}$ & - & - & - & - \\
\hline Oxford-csípő & 9 & $5(56 \%)$ & $4(44 \%)$ & - \\
\hline Risser 'plus' & 0 & - & - & - \\
\hline
\end{tabular}

(b) A közepes, nehéz vagy lehetetlen értékelések okainak megoszlása

\begin{tabular}{lccccc}
\hline & A & \multicolumn{3}{c}{ Felbontás } \\
\cline { 3 - 5 } & $\begin{array}{r}\text { 'közepes', } \\
\text { 'nehéz' és } \\
\text { 'lehetetlen' } \\
\text { értékelések } \\
\text { száma }\end{array}$ & Felbontás & $\begin{array}{c}\text { Pozicioná- } \\
\text { lás }\end{array}$ & $\begin{array}{c}\text { Technikai } \\
\text { probléma }\end{array}$ \\
\hline Sarokcsont & 42 & $3(7 \%)$ & $6(14 \%)$ & $33(79 \%)$ \\
\hline Nyaki csigolya & - & - & - & - \\
\hline Térd & 4 & $4(100 \%)$ & - & - \\
\hline $\begin{array}{l}\text { Módosított } \\
\text { Oxford-csípó }\end{array}$ & 3 & $3(100 \%)$ & - & - \\
\hline Oxford-csípó & 12 & $5(42 \%)$ & $7(58 \%)$ & - \\
\hline Risser 'plus' & 3 & $3(100 \%)$ & - & - \\
\hline
\end{tabular}

${ }^{1}$ A nyaki csigolyára vonatkozó eredményeket korábbi vizsgálatunk tartalmazza [9].

${ }^{2} \mathrm{~A}$ módosított Oxford-csípő a hagyományos módszerből számítható, így erre vonatkozóan nem végeztünk külön értékelést.

a tényleges biológiai kor bizonyos esetekben eltérhet, ami indokolja a kronológiai kornál „természetesebb” prediktor keresését.

Vizsgálatunk célja volt azon módszerek kiválasztása és értékelése, melyek a „kéz-csukló módszeren” kívül alkalmasak lehetnek EOS 2D/3D felvételeken a csontkor megállapítására.

Az irodalom áttekintését követően 10 korábban részletesen leírt és igazolt, de ritkábban használt csontkormeghatározó módszert találtunk. Ezek közül sokat a „csukló-kéz" módszernél is nagyobb problémát jelentő technikai gondok jellemeznek, mint a pozicionálási pontatlanságok vagy más csontok képbe vetülése (első borda, kulcscsont, könyök). Egy pilotvizsgálat után a kulcscsonton, az első bordán, a könyökön és a combcsontdiaphysisen alapuló méréseket kivitelezhetetlennek találtuk, valamint a vállmódszer is túl nehezen alkalmazhatónak bizonyult, mivel az esetek 54-72\%-ában komoly problé- 

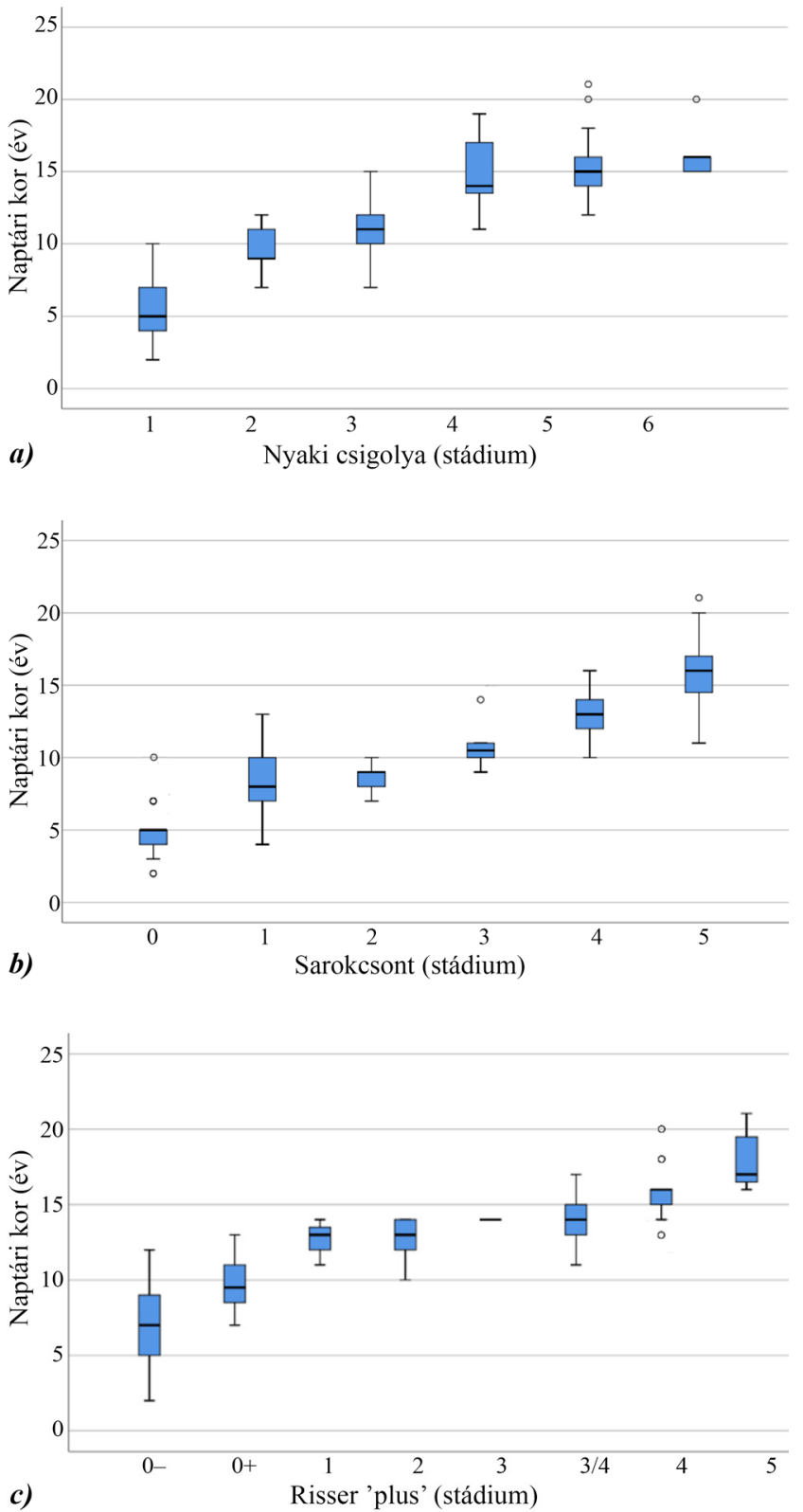

2. ábra

A vizsgált módszerekkel mért csontkorstádiumok naptári kor szerinti megoszlása dobozábrákkal ábrázolva (Csak a legrelevánsabb módszerek eredményeit mutatjuk)

(a) Hassel-Farman szerinti nyakicsigolya-módszer

(b) Nicholson szerinti sarokcsontmódszer

(c) Risser 'plus'-módszer (Negrini et al. után)

mát jelentett a vizsgált régiók megfelelő értékelése. Vizsgálatunkba végeredményben 5 módszer került be.

A „nyakicsigolya-módszer” az esetek nagyon nagy százalékában alkalmazhatónak bizonyult, a röntgenképek 98\%-a volt értékelhető. Mindössze 6 stádiumot tartalmaz, így megtanulása is egyszerú, megbízhatósága magas, gyorsan alkalmazható, és stádiumai széles életkort fednek le 7-től 21 éves korig.

A csípő körül két módszert találtunk könnyen alkalmazhatónak: a vizsgálat céljától függően a Risser 'plus'és az Oxford-módszer segítségével értékelhető a régió.
A Risser 'plus'-módszer minden röntgenen alkalmazható, gyorsan elvégezhető, megbízhatósága magas, és a Risser-stádiumok a legtöbb klinikus számára ismertek. Ráadásul az Y-porc fúziója alapján a fiatalabb korosztály is jobban kategorizálható, mint a klasszikus Risser-beosztással [43].

Az Oxford-féle csípőmódszer a maga 45 pontos skálájával a jelen vizsgálat során használt teljes életkori spektrum lefedését szolgálja, továbbá meghatározása kevés nehézséggel jár, melyek túlnyomórészt a kistomporral kapcsolatosak. Amíg az Oxford- és a módosított Oxfordmódszer esetén összességében csak a képek 8\%-a, illetve 3\%-a esett a „nehéz” kategóriába, addig 17 esetben (15\%) mutatkoztak problémák a kistompor megítélése során. Ezek a kistomporral kapcsolatos nehézségek, melyek már más szerzők által is említésre kerültek korábban $[30,44]$, valószínúleg szerepet játszanak az alacsonyabb megbízhatósági értékek megjelenésében a módosított Oxford-módszernél, tekintve, hogy az 5 meghatározott anatómiai pont közül ez alkotja az egyiket. Megoldásként a kistompor meghatározásának elhagyása [44] vagy az Acheson-féle életkortáblázat segítségével a csípő egységként történő értékelése merült fel [23]. Az ülőcsont megítélése is nehézséget jelenthet, hiszen a negyedik és a lezáró (8.) stádium röntgenmegjelenése megegyezhet. Az Acheson-féle életkortáblázatra alapozva, melyet vizsgálatunk tapasztalatai is alátámasztanak, 16 éves kor előtt nem jelenik meg a 8., lezáró stádium, így addig az apophysis hiánya a 4 . stádiumra utal. A módszer másik hátránya, hogy ez a legidőigényesebb az alkalmazottak közül, mindazonáltal kutatási célra ez javasolt a leginkább, hiszen a teljes vizsgált életkort lefedi, több régiót értékel, és sok stádiumot különít el.

A Nicholson és mtsai által leírt sarkcsonti módszerrel kapcsolatosan vegyes tapasztalataink voltak [30]. A sarokcsont egyszerüen megítélhető, és a módszer gyorsan tanulható, illetve memorizálható, továbbá nagyon magas, vizsgálón belüli és vizsgálók közötti megbízhatósági értékekkel bír. Másrészről a képről lemaradó vagy egymásba vetülő anatómiai pontok miatt a 114 képpárból 15 esetben (13\%) nehéznek, 14 esetben (12\%) pedig lehetetlennek bizonyult a sarok értékelése, így alkalmazásának feltétele a pozicionálásra fordított kiemelt figyelem.

A térd megítélése majdnem mindenképpen lehetséges volt (114-ből 113 esetben), mégis számos probléma merült fel ezzel a módszerrel kapcsolatban. A beosztás első stádiuma viszonylag magas életkorban jelenik meg (10,2 $\pm 1,4$ év - addig 0 . stádiumot nevezünk meg), tehát a módszer fiatal életkorban nem alkalmazható. A vizsgálók szubjektíve gyengébbnek ítélték a megbízhatóságát, és több kivitelezési nehézségről számoltak be. Sok időt igényelt az 1-3-as stádiumok meghatározása, mivel a relatív keskeny epiphysealis lemezek közti fúzió mértékének értékelése csak tökéletes anteroposterior és oldalirányú felvételeken kivitelezhető teljes biztonsággal. Összességében az átlagos mérési idő nem bizonyult magasnak, 
mert a képalkotások több mint fele a gyorsan meghatározható 0 . stádiumba esett. Amennyiben külön értékeljük az l-es vagy az e feletti stádium értékeléséhez szükséges időt, átlagosan 78,3 másodpercet kapunk (a 0. stádium megítélése átlagosan 27,9 másodpercet vett igénybe). Amíg O’Connor és mtsai szerint [28] a módszer könnyen tanulható, mi mégsem tapasztaltuk olyan logikusnak és átláthatónak, mint az alkalmazott többi metódust. Összességében tehát nem tudjuk kijelenteni, hogy EOS-képalkotás mellett a térdmódszer lenne a leginkább alkalmazható eljárás.

Vizsgálatunk korlátját jelenti, hogy a relatív alacsony elemszám (114 eset) oszlik 18 korcsoportra, így kevés az egy-egy életkori csoportba kerülők száma, azonban törekedtünk arra, hogy az egyes életkorokból azonos számú esetet vonjunk be, így bízunk az eredmények reprezentativitásában. Annak megítélése, hogy egyes módszerek „jobbak” vagy „kézenfekvőbbek”, mint mások, erős szubjektív faktort is tartalmaz a vizsgálók részéről, így az ilyenfajta beosztások eredményeinek értékelésekor figyelembe kell venni a humán faktort. Az általunk alkalmazott rendszer elönyben részesítette azokat a módszereket, amelyek több anatómiai pontot értékeltek, mert itt nehezebb volt „lehetetlen” kategóriába sorolódni, és könnyebb volt jobb megbízhatósági eredményt elérni. A közlemény során törekedtünk arra, hogy bemutassuk az általunk szerzett tapasztalatokat és felfedezett nehézségeket, hogy minél több, a napi gyakorlatban alkalmazható információt osszunk meg az olvasókkal.

\section{Következtetések, javaslatok}

10 csontkormérési módszer klinikai alkalmazhatóságát vizsgáltuk meg EOS-felvételeken, melyek közül 5 bizonyult kivitelezhetőnek: a nyaki csigolya, a csípólapát, a csípő, a térd és a sarkcsont értékelésén alapuló módszerek. A módszerek megbízhatósága kiválónak bizonyult, a térdalapú módszer kivételével, mely jó eredményt ért el. A módszerek az esetek több, mint 89\%-ában könnyen kivitelezhetőnek bizonyultak a sarokcsontalapú módszer kivételével, amelynél csak 63\%-ban volt könnyen megítélhető a régió. A méréshez szükség idő 17,5 és 149,0 mp között mozgott, elsősorban az értékelt régiók számától függően.

Reméljük, hogy a jelen közlemény rámutat az alternatív módszerek alkalmazhatóságára a csontérettség meghatározásában, miszerint „van élet a kézen és csuklón túl". Következtetésként javasolnánk, hogy amikor eldöntjük, milyen módszer alapján értékeljük a csontkort, több faktort is figyelembe kell venni: a vizsgált területet (alsó vagy felső végtag, ábrázolódik-e a kéz vagy a medence - hogy elkerüljük a felesleges sugárterhelést); a páciens életkorát (az Oxford-csípő-, a nyakigerinc- vagy a sarokcsonti módszer jobb a fiatalabb életkorban, ellentétben a térd- vagy a Risser-módszerrel, melyek csak a pubertás környékén alkalmazhatók), valamint a feldolgozásának „körülményeit” (tudományos vizsgálat esetén érdemes több időt szánni az Oxford-módszer használatára, míg a klinikai gyakorlatban egy gyorsabban elvégezhető mérés praktikusabb lehet). A Hassel-Farman szerinti, nyakicsigolya-alapú módszer tû́nik az arany középútnak, hiszen könnyen tanulható és alkalmazható, gyors, és közel az összes felvételen kivitelezhető volt.

Anyagi támogatás: A kutatás létrejöttét a GINOP-2.3.315-2016-00031. számú projekt támogatta.

Szerzői munkamegosztás: Minden szerző nagymértékben hozzájárult a tanulmányban bemutatott munkához. O’S. I.: A csontkor-meghatározásra alkalmas módszerek tanulmányozása, csontkor- és 3D EOS-rekonstrukciós elemzések, valamint statisztikai elemzések végzése, ábrák készítése, a kézirat összeállítása. S. Á. T.: A betegadatbázis összegyújtése, csontkor- és 3D EOS-rekonstrukciós elemzések elvégzése, a végső kézirat áttekintése. V. P.: Csontkor- és 3D EOS-rekonstrukciós elemzések végzése, a kézirat áttekintése. K. K.: A statisztikai elemzések elvégzése és a kézirat lefordítása. V. Cs., T. P.: A tanulmány megtervezése, a csontkor és az alsó végtagi paraméterek vizsgálatának felügyelete, a betegekkel kapcsolatos adminisztratív teendők elvégzése és az intézményi követelményeknek való megfelelőség biztosítása. A cikk végső változatát valamennyi szerző elolvasta és jóváhagyta.

Érdekeltségek: A szerzőknek nincsenek érdekeltségeik.

\section{Irodalom}

[1] Frank D, Rill L, Kolarovszki B, et al. Classical and modern methods for the assessment of skeletal maturation and pubertal growth spurt. [Klasszikus és modern vizsgálómódszerek a csontérettségi kor és a pubertáskori növekedési csúcs meghatározására.] Orv Hetil. 2018; 159: 1423-1432. [Hungarian]

[2] Greulich WW, Pyle SI. Radiographic atlas of skeletal development of the hand and wrist. Vol. 2. Stanford University Press, Stanford, CA, 1959.

[3] Björk A, Helm S. Prediction of the age of maximum puberal growth in body height. Angle Orthod. 1967; 37: 134-143.

[4] Fishman LS. Radiographic evaluation of skeletal maturation. A clinically oriented method based on hand-wrist films. Angle Orthod. 1982; 52: 88-112.

[5] Grave KC, Brown T. Skeletal ossification and the adolescent growth spurt. Am J Orthod. 1976; 69: 611-619.

[6] Acheson RM. A method of assessing skeletal maturity from radiographs; a report from the Oxford Child Health Survey. J Anat. 1954; 88: 498-508.

[7] Sanders JO, Khoury JG, Kishan S, et al. Predicting scoliosis progression from skeletal maturity: a simplified classification during adolescence. J Bone Joint Surg Am. 2008; 90: 540-553.

[8] Singer J. Physiologic timing of orthodontic treatment. Angle Orthod. 1980; 50: 322-333.

[9] Tanner JM, Whitehouse RH. Clinical longitudinal standards for height, weight, height velocity, weight velocity, and stages of puberty. Arch Dis Child. 1976; 51: 170-179.

[10] Hassel B, Farman AG. Skeletal maturation evaluation using cervical vertebrae. Am J Orthod Dentofacial Orthop. 1995; 107: 58-66. 
[11] Lamparski DG. Skeletal age assessment utilizing cervical vertebrae. Am J Orthod. 1975; 67: 458-459.

[12] Mito T, Sato K, Mitani H. Cervical vertebral bone age in girls. Am J Orthod Dentofacial Orthop. 2002; 122: 380-385.

[13] San Román P, Palma JC, Oteo MD, et al. Skeletal maturation determined by cervical vertebrae development. Eur J Orthod. 2002; 24: 303-311.

[14] Walker RA, Lovejoy CO. Radiographic changes in the clavicle and proximal femur and their use in the determination of skeletal age at death. Am J Phys Anthropol. 1985; 68: 67-78.

[15] Sauvegrain J, Nahum H, Bronstein H. Study of bone maturation of the elbow. Ann Radiol. 1962; 5: 542-550.

[16] Charles YP, Diméglio A, Canavese F, et al. Skeletal age assessment from the olecranon for idiopathic scoliosis at Risser grade 0. J Bone Joint Surg Am. 2007; 89: 2737-2744.

[17] Schaefer M, Aben G, Vogelsberg C. A demonstration of appearance and union times of three shoulder ossification centers in adolescent and post-adolescent children. J Forensic Radiol Imaging $2015 ; 3$ : 49-56.

[18] Schmeling A, Reisinger W, Loreck D, et al. Effects of ethnicity on skeletal maturation: consequences for forensic age estimations. Int J Legal Med. 2000; 113: 253-258.

[19] Michelson N. The calcification of the first costal cartilage among whites and negroes. Human Biol. 1934; 6: 543-557.

[20] Risser JC. The iliac apophysis: an invaluable sign in the management of scoliosis. Clin Orthop. 1958; 11: 111-119.

[21] Negrini S, Hresko TM, O'Brien JP, et al. Recommendations for research studies on treatment of idiopathic scoliosis: consensus 2014 between SOSORT and SRS non-operative management committee. Scoliosis 2015; 10: 8 .

[22] McKern TW, Stewart TD. Skeletal age changes in young American males analysed from the standpoint of age identification. Quartermaster Research and Engineering Command, Natick, MA, 1957.

[23] Acheson RM. The Oxford method of assessing skeletal maturity. Clin Orthop. 1957; 10: 19-39.

[24] Stasikelis PJ, Sullivan CM, Phillips WA, et al. Slipped capital femoral epiphysis: prediction of contralateral involvement. J Bone Joint Surg Am. 1996; 78: 1149-1155.

[25] Stull KE, L'Abbé EN, Ousley SD. Using multivariate adaptive regression splines to estimate subadult age from diaphyseal dimensions. Am J Phys Anthropol. 2014; 154: 376-386.

[26] Tsai A, Stamoulis C, Bixby SD, et al. Infant bone age estimation based on fibular shaft length: model development and clinical validation. Pediatr Radiol. 2016; 46: 342-356.

[27] Pyle SI, Hoerr NL. A radiologic standard of references for the growing knee. Charles C. Thomas Publisher, Springfield, IL, 1969.

[28] O'Connor JE, Bogue C, Spence LD, et al. A method to establish the relationship between chronological age and stage of union from radiographic assessment of epiphyseal fusion at the knee: an Irish population study. J Anat. 2008; 212: 198-209.

[29] Hoerr NL, Pyle SI, Francis CC. Radiological atlas of the foot and ankle. Charles C. Thomas Publisher, Springfield, IL, 1962.
[30] Nicholson AD, Liu RW, Sanders JO et al. Relationship of calca neal and iliac apophyseal ossification to peak height velocity timing in children. J Bone Joint Surg Am. 2015; 97: 147-154.

[31] Breen MA, Tsai A, Stamm A, et al. Bone age assessment practices in infants and older children among Society for Pediatric Radiology members. Pediatr Radiol. 2016; 46: 1269-1274.

[32] Dimeglio A. Growth in pediatric orthopaedics. J Pediatr Orthop. 2001; 21: 549-555.

[33] Tanner JM, Whitehouse RH, Cameron N, et al. Assessment of skeletal maturity and prediction of adult height (TW2 method). Academic Press, London, 1975.

[34] Schlégl ÁT, Szuper K, Somoskeöy S, et al. Three dimensional radiological imaging of normal lower-limb alignment in children. Int Orthop. 2015; 39: 2073-2080.

[35] Schlégl ÁT, O'Sullivan I, Varga P, et al. Determination and correlation of lower limb anatomical parameters and bone age during skeletal growth (based on 1005 cases). J Orthop Res. 2017; 35: 1431-1441.

[36] Szuper K, Schlégl ÁT, Leidecker E, et al. Three-dimensional quantitative analysis of the proximal femur and the pelvis in children and adolescents using an upright biplanar slot-scanning Xray system. Paediatr Radiol. 2015; 45: 411-421.

[37] Burkus M, Márkus I, Niklai B, et al. Assessment of sacroiliacal joint mobility in patients with low back pain. [A keresztcsonti ízület mobilitásának vizsgálata derékpanaszos betegcsoportban.] Orv Hetil. 2017; 158: 2079-2085. [Hungarian]

[38] Garamendi PM, Landa MI, Botella MC, et al. Forensic age estimation on digital X-ray images: medial epiphyses of the clavicle and first rib ossification in relation to chronological age. J Forensic Sci. 2011; 56(Suppl 1): S3-S12.

[39] Winer BJ. Statistical principles in experimental design. McGrawHill Book Company, New York, NY, 1962.

[40] Todd TW. Atlas of skeletal maturation. CV Mosby Company, St. Louis, MO, 1937.

[41] Stuart HC. Studies from the Center for Research in Child Health and Development, School of Public Health, Harvard University: I. The center, the group under observation, sources of information, and studies in progress. Monogr Soc Res Child Dev. 1939; 4: i-261.

[42] Bull RK, Edwards PD, Kemp PM, et al. Bone age assessment: a large scale comparison of the Greulich and Pyle, and Tanner and Whitehouse (TW2) methods. Arch Dis Child. 1999; 81: 172173.

[43] Little DG, Sussman MD. The Risser sign: a critical analysis. J Pediatr Orthop. 1994; 14: 569-575.

[44] Sanders JO. Maturity indicators in spinal deformity. J Bone Joint Surg Am. 2007; 89 (Suppl 1): 14-20.

(O'Sullivan Ian dr., Pécs, Akác u. 1., 7632 e-mail: iosullivan@gmail.com)

A cikk a Creative Commons Attribution 4.0 International License (https://creativecommons.org/licenses/by/4.0/) feltételei szerint publikált Open Access közlemény, melynek szellemében a cikk bármilyen médiumban szabadon felhasználható, megosztható és újraközölhetö, feltéve, hogy az eredeti szerző és a közlés helye, illetve a CC License linkje és az esetlegesen végrehajtott módosítások feltüntetésre kerülnek. (SID_1) 